\title{
Tectonic Archaeology as a Foundation for Geoarchaeology
}

\author{
Gina L. Barnes ${ }^{1,2}$ (D) \\ 1 Professorial Research Associate, SOAS University of London, London WC1H 0XG, UK; gb11@soas.ac.uk \\ 2 Project Affiliate, Department of Earth Sciences, University of Durham, Durham DH1 3LE, UK
}

\begin{abstract}
This article proposes a new subdiscipline, Tectonic Archaeology, based on the efforts of Japanese archaeologists to deal with the effects of earthquakes, volcanic tephra cover, and tsunami on archaeological sites. Tectonic Archaeology is conceived as an umbrella term for those efforts and as a foundation for Geoarchaeology in general. Comparisons distinguish between Geoarchaeology and Tectonic Archaeology, and a survey of major archaeological journals and textbooks reveals how the concept of 'tectonics' and specifically the processes of Plate Tectonics have been treated. Al-though the term 'tectonics' occurred fairly frequently, particularly as affecting coastlines and sea levels, it was not thoroughly defined and discussed. Volcanic activity was most mentioned in journals due to its provision of resources and modification of the landscape, while the 2011 earthquake and tsunami in Japan seems to have stimulated more studies in Archaeoseismology. The textbooks were found to have scattered references to Plate Tectonic processes but no clear approach tying these together. The major exception is the Encyclopedia of Archaeology which addresses volcanoes, Archaeoseismology, and tsunami-soon to be linked together vis à vis Earth processes. Tectonic Archaeology attempts first to explain the processes of Plate Tectonics to underwrite investigation of their effects; it is applicable worldwide, in continental and coastal contexts.
\end{abstract}

Keywords: Geoarchaeology; Plate Tectonics; Japan; disaster archaeology; Archaeoseismology; volcanic archaeology; Tsunami Archaeology; Archaeological Geology; Earth Sciences; subduction zones

\author{
In a nutshell, \\ Geoarchaeology, Archaeological Geology, and Landscape Archaeology \\ deal with the Earth's surface, \\ whereas Tectonic Archaeology begins with deep Earth processes \\ which contribute to the creation of that surface.
}

\section{A New Discipline of Applied Plate Tectonics?}

Plate Tectonics and Geoarchaeology both emerged as new fields of study in the early 1970s after many decades of incubation. By the mid-1980s, references were often made to tectonics in geoarchaeological works, particularly in the assessment of coastal and shoreline change as affecting human habitation. However, as indicated in the header to this article, the focus of Geoarchaeology developed to deal explicitly with the Earth's surface, entailing areal geomorphology, local sediments, site formation processes, the living environment, and accessible raw materials. In contrast, Tectonic Archaeology, as I propose, deals first with the deep Earth-particularly mantle convection in creating tectonic plates, in governing their movements, and in generating land parcels-and then with the nature of archaeological investigation that is constrained by tectonic processes affecting the local area. The creation of this term was stimulated by the development in Japan of three subdisciplines that deal with the effects of Plate Tectonics on archaeology: Earthquake Archaeology, TephroArchaeology, and Tsunami Archaeology. A holistic treatment of Tectonic Archaeology in Japan is forthcoming.

How different are Geoarchaeology and Tectonic Archaeology? It is proposed here that the fields of Geoarchaeology and its mirror discipline Archaeological Geology are 
centripetal: they begin with the archaeology and bring only disciplines and techniques into it that are helpful for analysing the anthropogenic record; we might also call it inductive for this reason because it begins with the archaeology, specifically the archaeological sediments, as also noted by [1] (p. 274), and works outwards. Tectonic Archaeology, on the other hand, is centrifugal: it begins with the geology and sets up expectations for what we might encounter in the material record emanating from it according to the location of the archaeological remains; in this sense it is deductive. Tourloukis [2], for example, offers a model based in tectonically active regimes to predict the locations of Palaeolithic sites. King and Bailey rightly note that tectonic phenomena characteristically operate over broad areas that reach far beyond an archaeological site and its catchment [1] (p. 274) in what is called "dynamic topography" [3] or "dynamic landscapes" [1,4,5].

The naming of a field is critically important, as it ostensibly defines the boundaries as well as the contents of work done under its name. Regarding the two subdisciplines based on the interface between geology and archaeology, Karl Butzer [6] described Geoarchaeolgy as "archaeology pursued with the help of geological methodology" versus Archaeological Geology as "geology pursued with an archaeological bias or application", as reported in [7] (p. 15). It is often difficult to distinguish between these, but Rapp and Gifford [8] (p. 52) proposed that they "do not characterize two ends of a spectrum of techniques but rather two contrasting and equally legitimate research goals"-while assignment to one or the other subdiscipline often depends "on the investigator and the project", not the content! Goldberg and Macphail go even further and dismiss this debate on definitions as entirely "irrelevant", proposing that "any issue or subject that straddles the interface between archaeology and the earth sciences" falls under the remit of Geoarchaeology [9] (p. 2). In a sense, I agree with their conflation of Geoarchaeology and Archaeological Geology, as I will employ the term Geoarchaeology to include both Archaeological Geology and Landscape Archaeology to act as the main discipline dealing with the Earth's surface.

Meanwhile, Tectonic Archaeology has a broader remit to include the Earth Sciences. It is a term designed to begin archaeological analysis from the deep end in order to describe and explain the resources, forms, and compositions that landmasses acquire and the geological processes they are subject to over time. Depending on where archaeological investigation is conducted, Plate Tectonics may be more or less relevant but never irrelevant, because all continental and insular landmasses ride on tectonic plates. McKenzie now distinguishes between oceanic tectonics and continental tectonics; he states that "The important difference between oceanic and continental tectonics is that deformation of continental lithosphere is distributed, rather than occurring on narrow plate boundaries" [10] (p. 6). Nevertheless, tectonic activity operates on both types of plates, whether along the margins or in the interior (intraplate). As examples of continental tectonics, even perceived 'stable' continental areas such as the Renish Shield in Germany can be subject to incipient rifting, generating much volcanic activity (e.g., [11,12]). In North America, there are other tectonic zones that have generated seismic and volcanic activity: the Midcontinent Rift, a horseshoe-shaped failed rift that runs from Oklahoma up around Lake Superior down to Alabama [13], accounting for volcanic rocks around Lake Superior; the currently active Rio Grande rift running from Leadville, Colorado to El Paso, Texas [14]; and the New Madrid Seismic Zone, affecting seven states in the central south [15]. Thus, continents, just because they are large, are not necessarily stable or uniform; both North America and China, for example, are composite blocks of many ancient cratons (the first of the Earth's crust to have formed) as shown in the United States Geological Survey-based map [16]. Knowing the rocks of an area (volcanic, metamorphic, or sedimentary) will provide clues to what kind of processes have acted on that area but not the extent of the structures they belong to: that is tectonics.

The most active tectonic regions of the world are modern subduction zones. These usually consist of oceanic plates being drawn under continental plates, setting off a series of associated seismic and volcanic processes. Present-day subduction zones occur primarily around the Pacific Ring of Fire (an out-moded term but still popularly used) and in 
the Mediterranean. But fossil subduction zones are inherent in collision zones, such as that causing the Himalayas, where the oceanic plate of the Tethys Ocean was subducted under Eursasia until the Indian continent collided with it. Such collision zones, also referred to as suture zones or mobile belts when completed, thus represent former active margins, i.e., fossil subduction zones. Such belts or zones may be sandwiched within present-day continental regimes, such as the Qinling Orogenic Belt in China or the Central Asian Orogenic Belt (CAOB). These zones/belts are often loaded with ores and other raw materials that have been important to previous inhabitants and often form important economic zones today. Pinpointing where both past and present subduction zones occur on the map, and understanding what they consist of, will assist the geoarchaeologist in assessing the potential resources and expected landform activity within their area of investigation-or nearby, whence materials could be mined or traded, or where natural hazards from subduction processes affected human occupation.

Perhaps the most outstanding works in Tectonic Archaeology without being named as such, is research by Bailey, King, and Force $[1,5,17,18]$. Working in the former Tethys subduction zone if the Mediterranean, these researchers begin their presentations with an ode to Plate Tectonics and continue to evaluate how tectonic activity has affected the landscape and, by extension, human habitation in their regions of interest. As King and Bailey have stated [1] (p. 271)):

Few attempts have been made to incorporate tectonics into palaeogeographical reconstructions of early hominin sites and their associated landscapes. Tectonic processes, if they are not ignored completely at this local scale, are usually treated as background events, as occasional disruption of sedimentary processes, or as sources of volcanic raw material for stone tools.

If this has been the case for studies in hominin evolution, how much truer has it been for general Quaternary archaeology? A 'background mention' only works if the reader fully understands that background, and few archaeology courses include holistic introductions to the disciplines of the Earth Sciences to allow geoarchaeologists to do so.

\section{Tectonic Archaeology Deriving from Japan}

It is not surprising that the idea for Tectonic Archaeology, as an umbrella subdiscipline to incorporate archaeological phenomena affected by Plate Tectonics, came from a Japanese context. The Japanese Islands occupy a modern subduction zone and its accompanying supra-subduction zone (the rifted Japan Sea back-arc basin). The archipelago is far less complicated geographically than the Mediterranean subduction zone, but its internal geology is quite complex. Japan is generally known as a volcanic island arc, but this obscures more than 500 million years of its formation which contribute to the Japanese landmass being $80 \%$ sedimentary in origin [19] (p. 468) [20]. These sedimentary accumulations include Accretionary Complexes (AC) that date to when the Japanese landmass was part of the continental edge prior to 16 million years ago. AC form primarily from trench fill that is 'bulldozed' into the continental shelf during subduction of an oceanic plate. AC also incorporate sporadic slices of oceanic floor (ophiolites), seamounts, and limestone reef fragments which were not subducted but obducted into the AC, and metamorphosed mantle rocks known as serpentinite melangés. Several AC have also been metamorphosed at deep levels then exhumed to the surface, adding to the complicated structure. Few AC are forming in the world today because subduction generally causes tectonic erosion of the continental edge instead of accretion. This is why the southwestern Japanese coast is of great scientific interest because accretion is still ongoing, forming the offshore Nankai prism.

Japan has inherited granite basements (batholiths) that formed on the continental edge before the rifting of the archipelago. These are the magma chambers of very ancient volcanic eruptions whose surface manifestations have all eroded away, and the unroofed batholiths now form the granite backbone mountain ranges of southwestern Inner Zone Japan. Present-day volcanic landforms date from several eruption phases beginning ca. 20 million years ago at the start of rifting. The footprint of Active Volcanoes is relatively 
small among Japan's mountainous character, which is primarily due to compression folding. Nevertheless, every square inch of Japan's surface has been subjected to tephra fallout at one time or another, or indeed multiple times. Tephra, however, is not the only volcanic product that might affect inhabitants: lava and gas emissions are also of concern. These have prompted researchers to propose a Volcanic Archaeology [21] instead of TephroArchaeology as constituted by Japanese researchers [22,23], and the name Archaeological Volcanology is also under consideration.

Together with volcanoes, earthquakes and tsunami are also subduction-zone hazards that must be endured. Landslides are also important consequences of earthquakes, but like tsunami, not all landslides can be assigned to earthquake activity, and no specific archaeological approach to landslides has yet been developed. Thus, the three subdisciplines of archaeology that have developed indigenously in Japan to monitor tectonic hazards in the archaeological record are jishin kōkogaku ('Earthquake Archaeology') [24], tsunami kōkogaku ('Tsunami Archaeology') [25], and kazanbai kōkogaku ('Volcanic Ash Archaeology') [23]. These can be bundled into a higher-order perspective that can be called Tectonic Archaeology.

\section{The 'Geo' in Geoarchaeology}

In distinguishing Geoarchaeology from Tectonic Archaeology, it is good to review how the Earth is treated in Geoarchaeology. 'Geo' has several meanings as a short form of 'geology' which itself is derived from the Greek the gê (from Greek gê, Doric gâ), meaning 'earth, land, country', with the connecting vowel -o- and -logia meaning the 'study of' [26,27]. All the translations of gê given above are appropriate to our discussion here, but let us select 'earth' as the most inclusive as it entails an increasingly large scope of research. The use of 'earth' in geoarchaeological writing can be considered on a scale of five levels from the particular to the general.

- Level 1 is 'earth' as dirt [28] (pp. 4,5) -the sediments of sites and their stratigraphic layering as recovered in archaeological excavation; this formed the topic of the first conference in Geoarchaeology in 1973 [29]. The focus on sediments by Schiffer [30] aimed at understanding site formation as a product of human behaviour; investigating stratigraphy was thus a tool for an 'anthropological archaeology' approach, aiming to reconstruct people's place in their environment (Level 4, see below). The attention given to anthropogenic layers- to the exclusion of the natural stratigraphy of archaeological sites-stimulated Karkanas and Goldberg [31] to propose a reorientation to the 'sedimentary matrix': treating artefacts, features, and anthropogenic sediments not as the primary focus but as components equal to natural sediments in an archaeological deposit.

- Level 2 is 'earth' as landforms - this is a geomorphological approach which outlines the nature and form of rocks and sediments as they occur in different environments: wet, dry, glacial, desert, fluvial, colluvial, etc. The volumes by Stein and Farrand $[32,33]$ address these different forms of sedimentary sources and processes but mention tephra and tephrochronology only in passing.

- Level 3 is 'earth' as resources-raw materials that can be turned into artefacts. Identifying sources of raw materials is a geological exercise, while matching artefacts to their sources is generally the province of archaeometry involving geochemistry and mineralogy. A good example of this focus is the session on Geoarchaeology at the Geosciences '98 Conference at Keele University; the contents of the conference were determined by the volume's editor, Mark Pollard, who was then affiliated with the Department of Archaeological Science at the University of Bradford [34,35].

- Level 4 is 'earth' as terrane-the geology of a region which produces materials as both sediments and raw materials. Terrane is different from 'terrain', the latter essentially topographic. The geological meaning of terrane is, according to ITA [36] (unpg.):

A rock formation or assemblage of rock formations that share a common geologic history. A geologic terrane is distinguished from neighboring terranes 
by its different history, either in its formation or in its subsequent deformation and/or metamorphism ... An exotic terrane is one that has been transported into its present setting from some distance.

Although Japanese geologists consider the geotectonic belts making up Japanese landmass as terranes bounded by faults, recent research elsewhere suggests that terranes need not be fault bounded and that the boundary between terranes evolves over time [37]. The origin and formation of terranes, both autochthonous (including cratons) and allochthonous, are one aspect of what Tectonic Archaeology seeks to provide for understanding the locale of archaeological research.

- Level 5 is 'Earth' as a sphere covered by mutually moving and self-reorganising tectonic plates which entail billions of years of Earth's history. The changing tectonic context of any particular plate or fragment thereof is what provides the geological variety created over time. That variety is the product of specific geological processes, particularly at the edges of the plates and their fragments in active subduction zones, as plates subduct one under the other, collide to form mountain ranges, or accrete intra-oceanic terranes. The various processes that occur within subduction zones include some of the natural hazards that affect society as mentioned above: volcanic eruptions, earthquakes, and tsunami-obvious targets of a Tectonic Archaeology. Once activity ceases in a former subduction zone, the geological products of those processes are frozen into the body of the Earth's crust in mobile belts, suture zones, and fossil subduction zones-or eroded to provide trench fill for future AC or metamorphic belts. These zones may currently occupy inland positions, so that Tectonic Archaeology is not limited to currently active subduction zones.

- Level 6 is 'earth' as environment: the living and non-living stage for habitation on the continents and oceans carried by tectonic plates. This is the realm both of Environmental Archaeology (à la (Butzer [6]) and the Earth Sciences themselves, as the oceans, atmosphere, even other heavenly bodies are taken into account. Geologists no longer find themselves between a rock and a hard place but in the company of vapours, liquids, thunder and lightning....and a lot of biomatter.

The above scalar effects within the concept of 'earth' are seldom addressed in Geoarchaeology (but see Stein [38]); discussions of methods and techniques are typically applied within one of the above levels. Moreover, Geoarchaeology did not evolve in this ordering of the levels. Environmental Archaeology (Level 6) was an early concern as proposed by Butzer [6], preceding Waters' emphasis on Level 1 stating that the job of the geoarchaeologist is to reconstruct "the geological factors of the human ecosystem from the sediments and soils" [39] (p. 6). Level 2 was the focus of Stein and Farrand [32,33] in their categorising landscapes and sediments according to their geomorphological formation, in order to assess the cultural geography in different time periods. Level 3 forms the arena of Archaeological Science, particularly in identifying the raw materials and their sources as made into artefacts. Levels 4 and 5 are the domain of Tectonic Archaeology, which has heretofore been excluded from holistic characterisation for archaeology and which is our current concern.

\section{Tectonics in Geoarchaeology}

The history, development, and definition of the field of Geoarchaeology have been extensively covered by many authors (e.g., [7,8,35,38,40-46]) and need no repetition here. Furthermore, having neither long experience in the field nor resources to investigate the voluminous geoarchaeological literature, my review in the following sections takes a different tack and examines an arbitrary selection of the major geoarchaeological books and the main scientific archaeology journals. Though these works are familiar to all geoarchaeologists, I review them here especially to assess previous appearances (or not) and uses (or not) of tectonics in its general form as well as in the specific subduction-zone processes of 
volcanic activity, earthquakes, and tsunami. The 2009 edition of Geoarchaeology [45], the major textbook of the field, gets an in-depth look below.

We can take a definition of tectonics from Keller and Pinter as referring to "the processes, structures, and land-forms associated with deformation of the Earth's crust" [47] (p. 1). The authors calculate that subduction zones account for $15 \%$ of the Earth's surface, but they point out first, that deformation is distributed over a much broader zone up to several hundred kilometres wide (as in the Andes), and second, that unstable areas can occur within continents, as we noted above. Intraplate tectonic activity is often due to the incipient development of oceans: rifting, as in the Red Sea or the Great Rift Valley in East Africa; or the North Sea rift isolating the British Isles from mainland Europe; or in the North American Midcontinent Rift or the Rio Grande Rift as noted above. Another intraplate volcanic activity is the mobile hot spot locations producing the Columbia River Basalt Province and Yellowstone, and the Siberian and Deccan Traps; or new activity in former subduction zones around ancient cratons such as the distributed volcanic fields along the southern edge of the Colorado Plateau, or the complicated geological subsurface fault system of the New Madrid seismic zone affecting seven states in the south-central United States. These examples were chosen to counter the 'faulty' idea that large continental interiors have nothing to do with Plate Tectonics. Additionally, of course, any place that has mountains is an orogenic (Greek òros mountains + gèneis) zone related to an ancient or operating subduction zone.

The term 'tectonics' is used here as a cover term for Plate Tectonics and all its associated processes. Geologists may object to the application of the adjective 'tectonic' to archaeology. However, this word simply refers to 'building' or 'construction', deriving from Greek (tektōn 'carpenter, builder'). In the archaeological context, it can be taken to indicate that societies are often structured or constrained by tectonic processes, and archaeological sites will contain structural evidence of tectonic activities-often to the detriment of their contemporaneous occupants. Tectonic Archaeology is thus surely a more relevant term than, for example, the 'tectonics of transcultural transactions' [48] (p. 123). Even the use of 'tectonic plates' has moved beyond its original context when historians and journalists speak of shifts in the tectonic plates of political relations and state systems, etc. Back when the term was first being developed $[49,50])$, geologists objected to the use of the term 'Plate Tectonics' outside of the strict meaning of the kinetics of moving plates on a sphere. An archaeological application, therefore, seems acceptable sensu lato. As mentioned above, the value of an overall Plate Tectonics approach to assessing archaeological sites and remnant human behaviour can be seen in earlier work of researchers (e.g., [17,18,51]), who nevertheless did not use the term 'Tectonic Archaeology' themselves.

In their textbook, Geoarchaeology, Rapp and Hill state that: "One of the major integrating concepts in the earth sciences is that of tectonics. Many of the geologic and biologic features associated with the archaeological record can be more fully understood within the context of plate-tectonic theory" [45] (p. 188). Despite this, their textbook, discussed below, had very little explanation of tectonics itself. In promoting the study of Plate Tectonics for archaeologists, we should heed the instructive comments by George 'Rip' Rapp on how difficult it is to grasp another field; as a prominent Archaeological Geologist; he stated, "I was fairly narrowly trained in mineralogy and geochemistry. It has been an uphill struggle for me to learn the necessary other earth sciences and the relevant archaeology" [52] (p. 11). We archaeologists need to do the opposite: we need a grounding in Plate Tectonics, and to do so, it is impossible to avoid having to "master the geoscientific jargon and literature" [33] (p. xii). We have to work hard to understand sister disciplines, but the effort is well worth it. In that vein, we should not hesitate to use geological 'jargon', for this is the language of the field that we need to understand.

Geology and archaeology are sometimes each treated as holistic entities; this is far from reality in that both disciplines have developed many subdisciplines and specialisms over the decades, with much specialist jargon. Moreover, the field of geology itself has been encompassed within 'Earth Sciences' or 'Geosciences' (see an interesting distinction in [53]). 
Earth Sciences include geophysics, geochemistry, oceanography, seismology, petrology, sedimentology, marine geology, paleontology, and many more. Dan McKenzie, author of plate kinetics, laments that though he studied geology (stratigraphy, sedimentology and paleontology) what he really needed was "fluid dynamics, earthquake seismology, petrology and geochemistry"; and more than just self-study from textbooks, he says he needed to learn to think like a scientist in those fields [10] (pp. 15, 16). If it was difficult for geologists and physicists, like Rip Rapp and Dan McKenzie, to come to grips with all of Earth Sciences, then how easy is it for archaeologists to gain a foothold knowledge? Kearey et al. [54] (p. ix) show us that we are not alone in grappling with this problem of coming to terms with Earth Sciences, for they are all-encompassing:

The initial impact of the plate tectonic concept, in the fields of marine geology and geophysics and seismology, was quickly followed by the realization of its relevance to igneous and metamorphic petrology, paleontology, sedimentary and economic geology, and all branches of geoscience. More recently its potential relevance to the Earth system as a whole has been recognized. In the past, processes associated with plate tectonics may have produced changes in seawater and atmospheric chemistry, in sea level and ocean currents, and in the Earth's climate ... This extension of the relevance of plate tectonics to the atmosphere and oceans, to the evolution of life, and possibly even the origin of life on Earth is particularly gratifying in that it emphasizes the way in which the biosphere, atmosphere, hydrosphere, and solid Earth are interrelated in a single, dynamic Earth system.

Geoarchaeology has heretofore grown out of archaeological investigation where problems are addressed or solved by techniques from Earth Science disciplines, ad hoc as needed. Although seldom addressed directly, several aspects of Plate Tectonics play a role in geoarchaeological assessments, and following McKenzie's advice, we geoarchaeologists really need to learn to think more like Earth Scientists in taking whole Earth processes into account in our research planning.

A survey, as offered in the next section, of how tectonics has been thus far integrated into geoarchaeological writings illustrates the extent to which it is considered an adjunct rather than a foundation. Since the concept of Plate Tectonics was not formally accepted until 1965 [55], it is unrealistic to expect references to it in the geoarchaeological literature before the 1970s. This will be the threshold for examining below the occurrence of the four aspects of Tectonic Archaeology (Plate Tectonics, earthquakes, tsunami, and volcanism) in the literature; certainly, each has been addressed for its own sake, but to what extent? The following sections will look at the way these aspects are addressed in select edited books, textbooks, and the major journals. These publications and others have myriads of case studies in their references, which have not been cited here.

\subsection{Tectonics in Major Scientific Archaeology Journals}

The archives for the journals Archaeometry and Geoarchaeology are maintained by the Wiley Online Library [56], while those of the Journal of Archaeological Science (JAS) are maintained by Elsiever ScienceDirect [57]. The numerical searches of these archives were augmented by a counting exercise for JAS, indicating some trends in the popularity of topics (Table 1).

\subsubsection{Archaeometry, 1958}

Published by Wiley on behalf of the Research Laboratory for Archaeology and the History of Art at the University of Oxford, and currently edited by Mark Pollard, Edward Hall Professor of Archaeological Science, Oxford, the journal Archaeometry covers international research in 'applied science': applying physical and biological science techniques to archaeology, anthropology, and art history. Topics covered include dating methods, artefact studies, mathematical modelling and analysis, remote sensing technology, conservation science, environmental reconstructions, demographics, and archaeological theory. Search- 
ing all of Archaeometry's volumes in Wiley Online returned 87 mentions for tectonic(s), including 29 for Plate Tectonics-but none of these were in the article titles; 39 for earthquake(s); 21 each for tephra and seismic (mainly relating to discovery surveys) but 0 for Archaeoseismology; and 4 for tsunami. The surprise was that despite emphasis on dating methods, tephrochronology only garnered one mention; and volcano-related topics were by far the most numerous at 355 mentions.

Table 1. Totals of journal online searches (maxima in bold).

\begin{tabular}{|c|c|c|c|c|}
\hline Search Term: & $\begin{array}{c}\text { Archaeometry } \\
1972-2020\end{array}$ & $\begin{array}{c}J A S \\
1974-2020\end{array}$ & $\begin{array}{c}\text { Trends in Journal of } \\
\text { Archaeological Science (JAS) }\end{array}$ & $\begin{array}{c}\text { Geoarchaeology } \\
\text { 1986-2020 }\end{array}$ \\
\hline Tephra & 21 & 130 & increasing from 2009 & 97 \\
\hline Tephrochronology & 1 & 22 & increasing from 2011 & 22 \\
\hline Tectonic(s) & 87 & 239 & doubling from 2007 & 333 \\
\hline Volcano & 355 & 203 & $\begin{array}{c}\text { common between } 2009 \\
\text { and } 2014\end{array}$ & \multirow[t]{2}{*}{353} \\
\hline Volcanic & & 664 & prolific between 2008 and 2015 & \\
\hline Earthquake & 39 & 125 & highest in 2011 & 137 \\
\hline Seismic & 21 & 80 & most in 2010 and 2013 & 312 \\
\hline Archaeoseismology & 0 & 3 & mentioned in 2006 and 2009 & 12 \\
\hline Tsunami & 4 & 28 & most between 2012 and 2013 & 59 \\
\hline
\end{tabular}

Pollard states that "There is a continuing need to further develop the theoretical underpinning of materials study in archaeology, including methods for the better integration of scientific provenance studies with existing archaeological understanding" [34]. According to Pollard's staff page [35], he is a member of the RESETconsortium (Response of Humans to Abrupt Environmental Transitions), which is charged with research on:

human palaeontology, archaeology, oceanography, volcanology and past climate change in order to investigate how our ancestors coped with rapid changes in climate during the last 80,000 years.... RESET aims to construct a new improved chronological framework for Europe using volcanic ash layers (tephra horizons) which represent time-parallel signatures allowing archaeological and geological records to be linked. [58]

In 2013, a new Open Journal of Archaeometry began publication; it is a peer-reviewed, publication fee-charging, Open Access, international scientific journal published by PAGEPress in Pavia, Italy. It currently has no Editorial Board, and published articles have declined to one to two per issue. Do not confuse this with the time-honoured Archaeometry from Oxford.

\subsubsection{Journal of Archaeological Science, 1974}

A year after the 'first' geoarchaeological symposium in Southampton in 1973 [29], a new Journal of Archaeological Science was initiated by a primarily British editorial board but published by Academic Press in New York. The leading article was by Butzer, a member of the board, on the analysis of Acheulian calc-pan sites and in which he used the term 'geo-archaeology' [59]. Thus, it might be understood that Geoarchaeology is a subdivision of Archaeological Science. However, in the twelve years from 1974 to 1986, the first article title in the Journal of Archaeological Sciences to incorporate the term 'Geoarchaeology' did not appear until March 1983, and the term within titles occurred only three times before 1986.

These articles were accompanied by many other Earth science topics: dating methods, stone-tool petrography and sourcing, sediment analysis and micromorphology, rockmineral-metal analyses and technologies, archaeomagnetism, erosion processes, ceramic petrography, trace element and isotope analysis, and the beginnings of Landscape Archaeology and palaeogeography. Nevertheless, as Edwards [60] wrote in his 'anatomy' of the 
first nine years of the Journal of Archaeological Science, the majority of articles published there $(52.3 \%)$ were biological; moreover, he discerned that most of the articles during those years were written from an inductive standpoint, i.e., without overarching problem-orientation, not even overtly of environmental reconstruction.

Edwards made a division between 'materials' and soils/sediments, that is, he distinguished between artefacts analysed by various Earth science techniques versus geological treatment of the major product of archaeological excavation-Renfrew's 'dirt'. Materials analyses had been published in the journal Archaeometry beginning from 1958. In contrast, the fact that bioarchaeological articles in the Journal of Archaeological Science were in the majority meant that the journal was clearly catering to a new outlet in the biological sciences for publishing on the results of flotation and fine sieving and faunal analysis by bio-archaeologists. How has this orientation fared over the last 35 years or so?

Articles and book reviews in JAS are indexed online from 1986 (vol. 13); the journal is now published by Elsevier [57], with Marcos Martinón-Torres (a materials specialist) and Robin Torrence (an archaeological volcanologist) as current editors. Stats on an Elsiever online keyword search are given in Table 1. 'Tephra' returned 130 entries, dramatically increasing in number after 2008; 22 entries for 'tephrochronology', increasing in number from 2011; 239 entries for 'tectonics, doubling from 2007; 203 for 'volcano', most common between 2009 and 2014, and 664 for 'volcanic,' most prolific between 2008 and 2015; 125 for 'earthquakes', highest numbers in 2011; 80 for 'seismic', most common between 2010 and 2013; whereas 'Archaeoseismology' only gets three mentions, in 2006 and 2009; 'tsunami' garnered 28 results, highest in 2012-2013. These stats show an interesting trend of growing interest in certain topics between 2006 and 2015 then tailing off, while volcanic issues are clearly the most prominent overall-paralleling the findings for the other two journals in Table 1.

Elsevier has developed a new sister publication, Journal of Archaeological Science: Reports, which reportedly focusses on the "application of scientific techniques and methodologies to all areas of archaeology"; however, in their advice to authors, they state: "If your article describes a new technique or has global significance please consider submitting to the Journal of Archaeological Science" [57] (emphasis added). It can only be deduced that the Reports series is for fieldwork reports-not earth-shaking research results.

\subsubsection{Geoarchaeology, an International Journal, 1986}

The journal Geoarchaeology was initiated in 1986 under the inspiration of Rhodes Fairbridge [46], then Professor of Geology at Columbia University. Fairbridge had a year earlier co-founded the Journal of Coastal Research [61]; his interests in coastal geomorphology dovetailed with those of early geoarchaeologists researching sea-level changes and coastal habitation.

A similar Wiley Online keyword search for Geoarchaeology as carried out above for Archaeometry returned the following as listed in Table 1: 'tephra' produced 97 entries, though 'tephrochronology' garnered only 22; 'volcano' /'volcanic' beat this with 353 entries; fewer entries contained 'earthquake(s)' at 137 entries, but 'tsunami' had a respectable 59. There were only 12 entries for 'Archaeoseismology' itself, but 'seismic' garnered 312.

\subsubsection{Journal Summary}

Examination of Table 1 clearly shows that volcano-related issues have been the most common topic in these journals-most likely because volcanoes and their magma chambers below produce resources such as granite, obsidian, andesite, and tuff that were and are still highly sought for the production of artefacts and building material. Volcanoes also produce lava and tephra that modifiy the landscape and affect human habitation. Tectonic processes such as these that are likely to wreak cultural destruction are entailed in another new subdiscipline, Disaster Archaeology (e.g., [62-72]), which is set to increase as a future topic in disaster mitigation and response management. Archaeological interest is possibly stimulated by the occurrence of modern disasters such as the Tohoku-oki earthquake and 
tsunami in Japan in 2011, corresponding to the increase of 'earthquake', 'seismic', and 'tsunami' entries between 2011 and 2013 in JAS.

\subsection{Books Creating Great Expectations}

Four books are reviewed here for their dealings with tectonic processes. The rise in journal articles over the decades, as demonstrated above, clearly indicates an interest and use of tectonic aspects by researchers on the ground. However, how are these conveyed to readers of such books listed below that aspire to be training or reference volumes?

\subsubsection{Archaeological Geology, 1985}

Rapp and Gifford introduced the new field of Archaeological Geology first in an article [8] and then in an edited volume [7]. Rapp and Gifford obviously treated their book as the coming of age of this new subdiscipline, echoed in Farrand's review of the book entitled "Birth of a discipline" [73] (p. 6). In contrast to earlier works on Geoarchaeology or Environmental/Ecological Archaeology - which had mainly been conceived by and aimed at archaeologists seeking to understand the broader, natural science framework of their own discipline- the stimulus for Archaeological Geology came primarily from professional geologists ( $80 \%$ of the contributors) who saw archaeology-related problems as a new frontier for their specialist applications [74].

Rapp and Gifford adopted Butzer's distinction between Geoarchaeology ("archaeology pursued with the help of geological methodology") and Archaeological Geology ("geology pursued with an archaeological bias or application") [7] (p. 15). Though choosing the latter for their title, Rapp and Gifford's book contained articles belonging to both of these categories without specifying which. Perhaps the clearest examples of doing geology with an archaeological bias are given in the chapters on geomorphology, coastal change, sedimentary environments, and the analysis of anthrosols. These geological processes were chosen for description because they affected human activities. Conversely, the chapters on doing archaeology using geophysical survey techniques, archaeomagnetism, tephrochronology, radiocarbon dating, and petrological analysis seem to fit precisely Butzer's definition of Geoarchaeology as applied science. Two chapters, however, on paleoenvironments and palynological applications to archaeology argued for an even broader title than geology itself, following the earlier line of enquiry into environmental reconstruction.

The volume, Archaeological Geology, began with a review of the historical connections between geology and archaeology, forming the introduction to the above topics. More detail was devoted to 19th-century collaboration, especially in the context of the emergence of archaeology as a discipline, than to recent developments. In fact, the editors postulated that there was a considerable decrease in archaeological collaboration with geologists after 1910, a state of affairs that was only rectified after 1970. Curiously, the editors omitted any serious discussion of Quaternary Studies as they relate to the investigation of all aspects of Pleistocene humans, a general problem still remarked upon 25 years later [75]. From this omission and the exclusion of physical anthropology references in the volume's bibliography, it might be inferred that this new subdiscipline as conceived of by Rapp and Gifford was meant to deal primarily with the environmental contexts of Holocene archaeology. This is in contrast to most early work of geologists on Palaeolithic sites. In Rapp's later publication with Hill, Rapp seems to see the extension of geology to the Holocene as a positive sign, as "the initially narrow scope of geoarchaeology (the antiquity of humans in the Old and New Worlds) will continue to broaden" [7] (p. 273).

\subsubsection{Earth Sciences and Archaeology, 2001}

This is an edited volume [76] that seeks to demonstrate how Earth Sciences are used in archaeology, giving practical information on why certain techniques were used and what kind of problems they would solve [76] (p. viii). It is not claimed to be comprehensive, with the editors noting what would have been good additions to the volume. Each chapter focusses on a specific subject or process, with Archaeoseismology being the only one that 
specifically deals with a tectonic process. Nevertheless, various aspects of tectonics are mentioned throughout the book. (Apologies to the various chapter authors for only citing page numbers below.)

- Tectonics: 'Tectonism' is mentioned in relation to Quaternary climate cycles but generally dismissed as not short-term enough to account for them [76] (p. 16). Among the processes mentioned are the movement of continental plates to northern latitudes; opening of the Atlantic Ocean, the Bering Strait, and connections to the Arctic Ocean, but the closure of the Isthmus of Panama, affecting ocean circulation; and the uplift of Tibetan Plateau and other mountain ranges [76] (pp. 16, 22). Volcanic eruptions and the dispersal of aerosols can affect climate [76] (pp. 16, 22), but also "rapid climatic changes can force volcanism" (stated on [76] (p. 17) without supporting evidence).

Cyprus is discussed as "a piece of Cretaceous oceanic crust that has been wedged upward...slowing of uplift might be due to a transition from a subduction to a strike-slip tectonic regime" [76] (pp. 128, 129). Unfortunately this piece of crust is not identified as the famous Troodos ophiolite, where you can 'touch the MOHO' (the Mohorovičić discontinuity)!

Tectonic activity ("uplift, subsidence, and lateral crustal movements") are noted as influencing sedimentation and erosion patterns and fluvial system adjustments, again over long timespans [76] (p. 67). River entrenchment and terrace formation may result from tectonic movements, while subsidence may result in no riverine downcutting [76] (p. 68). Tectonism is cited as one factor in determining regional variations in stream form [76] (p. 83). Furthermore, it is advanced that "Tectonically active regions provide unique niches for human occupation and food recsources.... Thus is it not surprising that we find occupation sites, especially for nonagrarian societies, along fault scarps and other tectonic landforms" [76] (p. 144). Nevertheless, tectonic depressions provide favourable conditions for soil formation [76] (p. 144).

- $\quad$ Earthquakes: Few authors mention earthquakes, though both landslide deposits and soft sediment deformation are used as evidence of seismic activity [76] (p. 67). In Peru, earthquakes are said to have traditionally been favoured agents of landscape change without consideration of other factors [76] (p. 116). The chapter on Archaeoseismology [76] (p. 143-172) is written in the vein of Archaeological Geology: using archaeology to illuminate incidences of palaeoseismology [76] (p. 144)—answering such questions as When did the earthquake occur? What did the earthquake do? When is the next earthquake?

\subsubsection{Practical and Theoretical Geoarchaeology, 2006}

This is a textbook written primarily for undergraduates by Paul Goldberg (now retired from Boston University) and Richard Macphail (Institute of Archaeology, UCL) [9]. The book is divided into three parts, the first of which is an introduction to geology with links to archaeological relevance and examples. The second section is entitled somewhat mysteriously as 'nontraditional' geological approaches; included here are discussions of cultural deposits, experimental archaeology, forensic Geoarchaeology, etc. The third section is a how-to introduction to field methods, lab techniques, and reporting and publishing.

- $\quad$ Tectonics: Tectonics are referred to six times in the text: as potentially causing mass movement of earth (landslides?) [9] (p. 84), as affecting groundwater and sea levels and erosion through tectonic movement and erosion [9] (pp. 99, 104, 114, 155), and as controlling folding and faulting [9] (p. 309).

- Tsunami: Tsunami are mentioned twice in the Coasts chapter, as depositing sediments and boulders on beaches.

- Tephra: In the Sediments chapter, tephra is defined as 'volcaniclastic debris'-including volcanic ash, lapilli, blocks, bombs, and pyroclastic flow debris-but assigned the caveat that these are "relatively uncommon in geoarchaeological contexts, as they are restricted to volcanic areas" [9] (p. 12), thus ignoring the widespread distribution 
of volcanic ash over hundreds even thousands of miles and the occurrence of distal cryptotephra in sediments-useful for tephrochronology.

Tephra deposition is not considered in the Aeolian Settings chapter except as a component of loess [9] (p. 141), despite the fact that a significant amount of fine-grained volcanic ash is distributed through the air during volcanic eruptions. One figure [9] (Figure 6.18), however, maps out distribution distances of aeolian deposits, distinguishing maximum dry distribution from even further maximum wet distribution of 'dust'. It is now widely acknowledged that tephra can be distributed thousands of miles, and cryptotephra can now be identified in sediment samples. This distinction (dry vs. wet) has not been emphasized in tephra studies per se.

Tephrochronology is alluded to but not named in relation to stratigraphic dating in Iceland [9] (p. 60), and the term does not appear in the index.

A particular soil type (Andic horizon) is specified as based on "the organic matter accumulation and weathering of volcanic ash (e.g., Tephra) to produce allophanes" [9] (p. 49); this is slightly incorrect as discussed in [77]. Moreover, the authors cite Tan [78] in stating that "soils formed in volcanic ashes (andosols) are easily worked and naturally fertile, as their high organic matter content encourages high biological activity" [9] (p. 63). The Japanese experience with andosols does not comply with this characterization, as andosols are highly unproductive in Japan precisely because of the presence of allophanes, mentioned above as diagnostic of Andic horizons [77].

The preservative effects via rapid burial by tephra [9] (p. 224) are mentioned in terms of Pompeii first of all but also of Edo-period field systems in Japan [9] (p. 64). Tephra layers can be extremely thick, but ground-penetrating radar can help locate subsurface features depending on their depth and composition of overlying strata [79].

- Earthquakes: This term does not appear in the index, nor does 'Archaeoseismology'. Nevertheless, among sedimentary structures, convolution and load structures are mentioned but not defined [9] (p. 24). Soft sediment deformation is pictured for lacustrine deposits and credited to earthquakes [9] (Figure 1.10).

- Flooding: Flooding is an inherent hazard with volcanic eruptions, as lava, pyroclastic flows, and lahars can clog and disrupt watercourses; a good place to have mentioned this (but was not) would have been in the listing of "major flow events, such as spring flooding or during exceptional events such as hurricanes and other storms" [9] (p. 89).

- Landslides: Landslides are mentioned as products of gravitational deposition [9] (p. 11), but they are not specifically discussed under "Slopes and Slope Deposits" [9] (ch. 4); however, mass movement of earth materials are acknowledged to occur in "well-known tectonically unstable areas" [9] (p. 84). Such areas seem to be confined to land, and the mass movements of continental slope materials to form turbidites in a subduction trench are not alluded to; these deposits are important as they make up the bulk of trench fill that then can be accreted to the continental edge as in the present-day Nankai Prism or the Cretaceous Shimanto Belt of Japan.

\subsubsection{Geoarchaeology, the Textbook, 2009}

Of all the books dealt with here, Geoarchaeology: the earth-science approach to archaeological interpretation [45] excites our greatest expectations, since it is designed as a textbook for teaching Geoarchaeology. It is a masterpiece in presentation of a vast and complicated set of geological conditions that archaeologists should be aware of. Since its original publication in 1998, it has served as the bible for geoarchaeological training.

Let us return to the authors' opinion that "One of the major integrating concepts in the earth sciences is that of tectonics. Many of the geologic and biologic features associated with the archaeological record can be more fully understood within the context of platetectonic theory" [45] (p. 188). How, then, are the processes and products of Plate Tectonics dealt with by Rap and Hill? Their book is a treasure trove of geoarchaeological knowledge, but how much is devoted to tectonics? 
The excerpts below, from the 2009 edition, indicate a piecemeal approach to the subjects, only as relevant to specific archaeological data or questions (the eclectic, inductive, centripetal approach mentioned in the introduction to this article). That approach assumes considerable background knowledge to make sense of what is offered. Without that background, questions about relationships abound: Why is andesite named after the Andes? What governs the occurrence of metamorphic rocks? What are the relationships between mafic and ultramafic rocks, or between granite and rhyolite and why are they found where they are? How can oceanic rocks such as serpentinite and limestone be found on land? Why are there earthquakes in New Madrid, Missouri? Is a sand blow accompanying an earthquake merely a "patch of coarse sandy sediment", and is it different from a "soil denuded of vegetation by wind action" [45] (p. 289)?

- Tectonics: The textbook only give a brief explanation of the theory of Plate Tectonics [45] (pp. 188, 189) under the section on Paleoenvironment Reconstructions [45] (pp. 188, 189). Among the processes mentioned are faulting, rifting, plate collisions, mountain building, earthquakes, and volcanism (the latter two are further treated under "Geologic Catastrophes" [45] pp. 257-262). Tectonic movements such as subsidence and uplift are said to sometimes be recovered from coring data [45] (p. 260), while tectonic plate boundaries are subject to earthquakes [45] (p. 261). The way these phenomena are presented appears to assume a reader's prior knowledge of at least geology if not Plate Tectonics per se.

- Volcanism: Rapp and Hill (2009) identify volcanic eruptions as major destructive forces, causing tsunami and volcanic ash fallout leading to climate change [45] (pp. 59, 163-165, 167) and the destruction of civilisation [45] (p. 190); but eruption pro-ducts also can provide habitation sites such as in lava tubes or caves cut into tuff [45] (pp. 85, 86). They quote D. Griffiths who emphasizes the "attractions as well as the hazards of life in an actively volcanic zone" [45] (p. 244) such as using volcanic flagstones in road building (p. 248), but they note that volcanic ash is a poor retainer of DNA [45] (p. 125).

Tephra layers, deposited on a minute-to-day scale [45] (p. 131) across the landscape [45] (pp. 27, 77, 150), are often termed "chronostrata" [45] (Figure 2.2); they function as key layers or marker tephra for correlating archaeological deposits across space [45] (Figure 2.6, pp. 27, 263), and providing for "good preservation of sites" [45] (p. 264). One major use of tephra in archaeology is tephrochronology [45] (pp. 136, 142, 143). Tephra in its various forms (lithified into tuff or weathered into clay) is as important as igneous rock for radiometric dating using isotopes of potasium $(\mathrm{K})$, argon $(\mathrm{Ar})$, lead $(\mathrm{Pb})$, and urananium (U): K/Ar, Ar/Ar, and Pb/U isotope decay dating [45] (figs 3.8 and 3.14, p. 146).

Volcanic vents can release 'dead' carbon that can skew radiocarbon dates in organic matter [45] (p. 151).

Igneous rocks are described individually [45] (pp. 208-210) but without noting their relationships or origins; such rocks and feldspar minerals in volcanic rocks can be dated with thermoluminescence [45] (p. 157), while hydration of broken edges of obsidian, a volcanic glass, can be measured to determine when the surface was fresh [45] (pp. 160, 161). A full subsection is devoted to obsidian sourcing [45] (pp. 225, 226, 229), while other igneous products [45] (Table 7.1) are defined and discussed [45] (pp. 209, 210, 226, 227); many are listed individually in their index.

In their section on Soil Types, tephrogenic soils (andosols/andisols) are not represented despite their abundance in New Zealand and Japan [78], but volcanic ash is noted as inhibiting the development of inceptisols [45] (p. 41). Interestingly, aeolian deposits of volcanic ash (or even loess) are not included in their discussion of sediment transportation by particle size [45] (p. 50), nor are cryptotephra mentioned in their short section on Micromorphology, despite their listing of "vitric (presence of glass shards or pumice)" as a modifier to describe palaeosols [45] (p. 45). Volcanic ash can be a prominent component of sedimentary layers [45] (p. 83) and tephra, even as ground-up tuff, can be used to make cement [45] (p. 214). 
Tephra and igneous rocks decompose to form clays [45] (pp. 212, 213): kaolinite, montmorillonite, smectite. Bentonite is included here as a 'rock' [45] (pp. 145, 215); it is rather a claystone made up of montmorillonite and/or beidillite clay [80]. Halloysite is not mentioned, while amorphous silica is mentioned but not identified as allophane [45] (p. 86); Volcanic ash and 'sands' can be used as ceramic temper [45] (pp. 229, 230), and electron-microprobe analysis has revealed ceramic pastes from distinct volcanic sources [45] (p. 238), while basalt in ceramic bodies can be characterized by SEM-EDS (Scanning electron microscopy with energy dispersive spectroscopy) [45] (p. 238). The geologic environments are given for native copper formation in mafic and ultramafic rocks [45] (p. 231). Volcanic materials are stated as prohibiting magnetic surveying because they already have "strong magnetic properties" [45] (p. 114), but granite itself can be assessed with magnetic susceptibility [45] (p. 238). Volcanic and geothermal regions can be detected with thermal infrared imaging [45] (p. 120).

The case studies that Rapp and Hill mention in relation to volcanics range from Tonga, Fiji, and Hawaii, across Alaska, American northwest, northern Rocky Mountains and the Great Plains, Lower Yellowstone, California, Belize, Guatemala, Mexico, Peru, Bolivia, Chile, to Iceland, Great Britain, France, Italy, Greece, Egypt, Crete, Turkey, Syria, Tanzania, Kenya, East Africa, and Indonesia (only Krakatoa)—but not the Philippines, Japan, nor New Zealand despite a map of volcanic eruptions [45] (Figure 9.6) that clearly indicates much activity in the western Pacific. Their listing of volcanic arcs [45] (p. 225) also omit Japan and New Zealand, unless they mistakenly include them in 'Southeast Asia'. (Japan is in East Asia, New Zealand is in Australasia; to those that work in these areas, these distinctions are important.)

- Seismicity: Perhaps because of Rapp's early involvement in this subject, his textbook with Hill devotes a long subsection to it, albeit under geologic 'catastrophes' [45] (pp. 257-262). Nevertheless, they propose that "Except over very small regions, devastating earthquakes historically have not caused cultural change" [45] (p. 190). Eric Force (e.g., [18]) would definitely challenge that. However, they do make the valid distinction that earthquake intensities (Modified Mercalli earthquake intensity scale [45] (Table 9.1) are more important to Geoarchaeology than magnitude (M) measurements. Some examples of archaeological destruction are given to compare with the modern intensity effects. However, they are careful to advise that earthquake damage in the archaeological record has to be proved, not assumed, as there may be multiple causes such as downslope collapse due to heavy rainfall.

Seismic maps are available to the geoarchaeologist [45] (pp. 103, 268); however, geological maps are stated not to have sufficient information on unconsolidated ground to assess seismic risk [45] (p. 260). Japan is mentioned along with the United States in having advanced methods to evaluate seismic risk [45] (p. 268). 'Geologic structures' in surface sediments resulting from earthquakes include sand dikes, sand pipes, slumps, faults, and joints, fissures, sand blows, landslides, and subsidence; seismic-reflection analyses can also identify slumped subsurface sediments due to previous earthquakes [45] (p. 260). The principles of seismology, developed in earthquake studies, have led to artificial seismic profiling [45] (pp. 117, 118), described as useful in reconstructing offshore coastal paleogeomorphology, harbours, and shorelines relevant to prior habitation; it can also locate shipwrecks.

Liquefaction features and convoluted bedding appearing in sediments are termed 'secondary structures' [45] (Figure 2.13); liquefaction [45] (p. 54), is acknowledged as a product of earthquake activity [45] (pp. 260, 261), while "contorted sediments can also be associated with spring deposits" [45] (p. 54) as well as with earthquakes. Faults (presumably small) are listed above as a product of earthquakes, created by stress [45] (p. 54); nowhere is it explained that movement on faults is the cause of earthquakes-it is the fracturing and movement of rock through stress that sends off seismic vibrations. Movement on faults is merely treated as another factor in addition to earthquakes that are "geologic problems for site preservation" [45] (p. 265) but apparently not as affecting previous settlement. Without 
providing clear distinctions, it seems that two aspects of earthquakes are being contrasted here: seismic shaking that may cause sediment deformation, and fault activities (strike-slip, normal, reverse) resulting in landmass displacement. The most interesting example of fault (or fissure) activity relates to the escape of hydrocarbon gases at Mount Parnassas leading to the intoxication of the oracle of Delphi via volcanic gas emissions [45] (p. 273). As above, using the archaeological record to illuminate seismic processes is described as Archaeological Geology [45] (p. 261).

- Tsunami: "Tsunami debris accumulation" is mentioned as an example of minuteto-day scale of geological activity [45] (pp. 131, 262) and tsunami are offered as examples of "violent cataclysms [that] normally do not prompt dramatic changes in human societies" [45] (p. 190). This statement is arguable in light of the Boxing Day tsunami of 2005 and the Japanese tsunami of 2011—or maybe these would be viewed as 'abnormal' situations. The authors link tsunami to risky coastal areas [45] (p. 257), such as accompanied the eruption of Krakatoa [45] (p. 263), but they fail to mention the tsunami damage associated with the Lisbon earthquake of 1755 [45] (p. 261) for which the tsunami was "accountable for most of the about 70,000 deaths in Portugal, Spain and Morocco" [81] (n.p., emphasis added). Tsunami can also occur on lakes [45] (p. 261), but the cause of such inland tsunami is not dealt with (cf. [25]). The authors list tsunami as one of the "Geologic problems in site preservation" [45] (p. 265, their emphasis).

\subsubsection{Encyclopedia of Geoarchaeology, 2017}

A hefty, authoritative, if not exhaustive, contribution to the field is the Encyclopedia of Geoarchaeology edited by Allan Gilbert [82]. Major aspects of tectonics are covered in individual entries in this encyclopaedia: Volcanoes and people, Archaeoseismology, and Tsunami. The field is moving forward! All that is missing is an explanation of Plate Tectonics to underwrite them, which will be rectified in the coming revised edition.

\subsubsection{Reflections on Books}

The above books are extremely rich and valuable compilations in the field of Geoarchaeology, but it is clear that tectonic processes and products are given short shrift in the overall presentations despite the fact that they have become more inclusive through time. Aspects of Tectonic Archaeology tend to be introduced piecemeal within certain geoarchaeological contexts, but they are not tied together into a coherent whole. Trying to cover all of geoarchaeological concerns in a single volume is a monumental task, and the efforts of these authors are valuable and appreciated. However, the results unequivocally illustrate that researchers in (currently or previously) tectonically active regions need specialist knowledge to anticipate and deal with their archaeological cases in regional context. There must be a wealth of data out there that has not yet been recognized, collected, and analysed precisely because tectonic processes and their products are relatively unknown by the investigating geoarchaeologists. This has been demonstrated in Japan by a single geomorphologist's efforts, beginning in 1985, to teach archaeologists how to recognize earthquake damage in archaeological sites [24]. Within eighteen months of the 1995 Kobe earthquake, a network of 'disaster concerned archaeologists' was developed, and 378 sites nationwide were identified as having previous earthquake damage [83].

\section{Reflections}

The literature review above has revealed a general awareness of the products of Plate Tectonics but little explanation of the processes. I argue that a little knowledge of such processes goes a long way. If the tectonic development of the fieldwork area in question is known from the beginning of a project, rather than appealed to in the analysis stage, Tectonic Archaeology undergirds but does not undermine geoarchaeological investigation. It is a valuable first step in understanding the regional geology, resources, and transformative processes that might have been (and maybe still are) responsible 
for landscape composition and change, and resource availability. Regardless of where geoarchaeologists work, they are dealing with a landscape that is grounded in Plate Tectonics. Instead of being "surface scientists", geoarchaeologists have a role to play in "subsurface science", which according to Bullough [84] (p. 27) "is only going to get more important in the context of a growing population, supporting sustainable development and preventing dangerous climage change."

It is reasonable, therefore, to say that if Tectonic Archaeology derives from Plate Tectonics, then all the processes and products of Plate Tectonics that occur on, contextualize, or have effects on archaeological sites are obviously subjects of Tectonic Archaeology. This includes landform changes and characteristics, as when pyroclastic flow ignimbrites form new terraces to be colonized, as when faulting displaces paths, roads, and rivers that may reroute communications across the landscape, as when tephra or tsunami sand deposition is so deep that it influences the land use and kinds of crops that can be grown on it, as when erosion due to uplift exposes resources like obsidian flows and jade veins to the surface, as when earthquakes cause landslides that add new soil to lowlands for exploitation ... Examples are innumerable. One of the points of Tectonic Archaeology is not to look beyond a site/feature/object itself to what natural causes beyond 'culture' and 'environment' might have influenced its location/accessibility/use, but instead to begin with tectonics and assess beforehand how the tectonic history of a region might have conditioned the landscape and biological environment in ways that cannot easily be assessed from a site/feature/object alone or in ways that would not be investigated otherwise.

Finally, it is necessary to point out the dichotomous nature of tectonic processes that may either act to destroy past evidence or preserve it, possibly within the same event. Sudden destruction is most often addressed within Disaster Archaeology, while the latter is the bread and butter of archaeological excavation. Once past disasters are acknowledged for a region, modern populations are behoved to monitor and mitigate against potential future disasters. These concerns include disasters that are not immediately tectonically based, such as climate change and flooding; but when Earth systems are considered as a whole, Plate Tectonics often lie at the base of or are inter-linked with other changes such as volcanic degassing/eruptions contributing greenhouse gases to the atmosphere, or the uplift of the Himalayas changing climate patterns in East Asia. Disaster Archaeology focusses on negative impacts, but the positive influences of Plate Tectonics should not be overlooked. For example, a paper on landslides of green tuff, deposited by Miocene submarine eruptions but now forming mountains in northwest Japan, identifies the green tuff as good for agriculture-in opposition to the generally poor quality of volcanic soils in Japan $[77,85]$.

It is always said of a Critical Graduate Student (which I once was but no longer) that it is not enough to criticize and demolish previous work but necessary to build a replacement. In response, I am writing a general introduction to Plate Tectonics for archaeologists of subduction zones as in Japan [86]. With Part I as a geological primer, I attempt to explain subduction-zone processes that relate to Japan's geographical positioning, and then examine the palaeogeographic compilation of the Japanese landmass from the time subduction began at 520 million years ago through the rifting of the archipelago at 16 million years ago, and finally the establishment of neotectonics and the Quaternary volcanic system. Subsequently, in Part II, introductions of the three main subdisciplines of Japanese archaeology dealing with tectonic processes are provided, with consideration of how they are related to Disaster Archaeology. Part III is offered as an example of regional Geoarchaeology in a tectonic framework. It is indeed a challenge to eke out the archaeological significances of Plate Tectonics for a specific fieldwork area, and in this case, it is only retrospective. This is actually a daunting task due to the fact that tectonic processes either have a long-term effect that is not noticeable within a human lifespan or a short-term effect that often only occurs sporadically. Archaeological research recovers time-slices of life at different intervals that may not match the geological events. 
Nevertheless, this approach, from the general (Plate Tectonics) to the specific (archaeological site), differs from normal geoarchaeological offerings which usually begin with a site and try to fit it into a large context. The fuller integration of Plate Tectonics, its processes and products, into geoarchaeological research from the beginning of a project cannot but assist understanding and broaden the scope of enquiry. Yes, human behaviour and activities are our target, but by understanding the tectonics of a region, we might understand more what to look for on both more subtle and widespread levels-for example, not removing tephra layers before understanding their timing and generation so that footprints and activity between tephra fallouts can be documented e.g., [70,87]; understanding that the deposit of chemicals across fields in a tsunami might be as devastating as sand cover in affecting crop growing [88]; or developing the ability to recognize and distinguish earthquake liquefaction traces from human-made features [24,89]; or understanding the differential distribution of precious nephrite and jadeitite resources across the globe as related to orogenic zones [90,91]. All this requires a greater engagement with Earth processes than the normal geoarchaeologist encounters in their training. By knowing the geological history as well as contents of the fieldwork region, questions might be asked that otherwise might not arise.

Meanwhile, there are many resources that provide a general introduction to aspects of Plate Tectonics and its use in associated disciplines. For a two-hour forty-minute introduction to Earth Sciences, see [92]. For more detailed explanations of Plate Tectonic processes, the first edition of Kearey and Vine on Global Tectonics [93] is a generally accessible textbook, while their second edition is highly technical [54]. Plate Tectonics [94] and Tectonics [95] give great detail and prolific citations. The volume on Active Tectonics by Keller and Pinter [47] is thematically organized and very readable but focussed primarily on earthquakes and geomorphology. Goldberg was cited above saying that in America, Geoarchaeology is geomorphology or it is nothing. From the 1970s, the field of Tectonic Geomorphology has concentrated on not just landscape description but landscape evolution-rates of uplift and landform displacement through time [96-99]. Thus, much recent writing on geomorphology is based on the processes of tectonics [48] (ch. 2), [100-102], though assessing such is not without problems [103]. This trend has been carried into archaeology $[75,104]$. In addition to the works mentioned above that recount the history of Geoarchaeology, the Preface of Goldberg et al. [76] describes several earlier volumes on Geoarchaeology that are worthy of note, some of which have also been dealt with here [29,45] and some not $[39,105]$. Among the myriad recent offerings, the most useful are $[9,33,45,78]$.

Funding: This research received no external funding.

Acknowledgments: Many thanks to Erin Li for this opportunity to publish an introduction to my forthcoming book on Tectonic Archaeology in this way. I also acknowledge MDPI support in having this article published in a timely manner. My comments here are generally in response to a fellow geoarchaeologist, who said flat out "I don't know anything about Plate Tectonics". Thank you for stimulating this attempt to discover what Geoarchaeology in general presents on the topic, and thanks to three reviewers who offered thoughtful critiques leading to better arguments here and interesting suggestions for future consideration.

Conflicts of Interest: The author has no conflicts of interest.

\section{References}

1. King, G.C.P.; Bailey, G.N. Tectonics and human evolution. Antiquity 2006, 80, 265-286. [CrossRef]

2. Tourloukis, V. The Early and Middle Pleistocene Archaeology Record of Greece: Current Status and Future Prospects; Amsterdam University Press: Amsterdam, The Nederland, 2010.

3. Hager, B.H.; Clayton, R.W.; Richards, M.A.; Comer, R.P.; Dziewonski, A.M. Lower mantle heterogeneity, dynamic topography and the geoid. Nature 1985, 313, 541-545. [CrossRef]

4. Bailey, G.N.; King, G.C.P. Dynamic landscapes and human dispersal patterns: Tectonics, coastlines, and the reconstruction of human habitats. Quat. Sci. Rev. 2011, 30, 1533-1553. [CrossRef]

5. King, G.C.P.; Bailey, G.N. Dynamic Landscapes and Human Evolution; GSA Special Paper 471; Geological Society of America: Boulder, CO, USA, 2010. 
6. Butzer, K.W. Archaeology as Human Ecology; Cambridge University Press: Cambridge, UK, 1982.

7. Rapp, G.R.; Gifford, J.A. (Eds.) Archaeological Geology; Yale University Press: New Haven, CT, USA, 1985.

8. Rapp, G.R.; Gifford, J.A. Archaeological geology. Am. Sci. 1982, 70, 45-53.

9. Goldberg, P.; Macphail, R. Practical and Theoretical Geoarchaeology; Blackwell: Malden, MA, USA, 2006.

10. McKenzie, D. A geologist reflects on a long career. Annu. Rev. Earth Planet. Sci. 2018, 46, 1-20. [CrossRef]

11. Schmincke, H.-U. The Quaternary volcanic fields of the East and West Eifel (Germany). In Mantle Plumes: A Multidisciplinary Approach; Ritter, J.R.R., Christensen, U.R., Eds.; Springer: Berlin, Germany, 2007; pp. 241-322.

12. Riede, F. Splendid Isolation: The Eruption of the Laacher See Volcano and Southern Scandinavian Late Glacial Hunter-Gatherers; Aarhus University Press: Aarhus, Denmark, 2017.

13. Stein, S.; Stein, C.A.; Elling, R.; Kley, J.; Keller, G.R.; Wysession, M.; Rooney, T.; Frederiksen, A.; Moucha, R. Insights from North America's failed Midcontinent Rift into the evolution of continental rifts and passive continental margins. Tectonophysics 2018, 744, 403-421. [CrossRef]

14. Murray, K.D.; Murray, M.H.; Sheehan, A.F. Active deformation near the Rio Grande Rift and Colorado Plateau as inferred from continuous global positioning system measurements. J. Geophys. Res. Solid Earth 2019, 124, 2166-2183. [CrossRef]

15. Eldridge, C.M.; Wolf, L.W. The tectonic framework of the New Madrid Seismic Zone from lidar, gravity, and magnetic modeling. Symp. Appl. Geophys. Eng. Environ. Probl. 2019. [CrossRef]

16. United States Geological Survey. North America Basement Rocks. 2019. Available online: https://commons.wikimedia.org/ wiki/File:North_america_basement_rocks.png (accessed on 19 March 2021).

17. Bailey, G.; King, G.; Sturdy, D. Active tectonics and land-use strategies: A Palaeolithic example from northwest Greece. Antiquity 1993, 67, 292-312. [CrossRef]

18. Force, E.R. Impact of Tectonic Activity on Ancient Civilizations: Recurrent Shakeups, Tenacity, Resilence, and Change; Lexington Books: Lanham, MD, USA, 2015.

19. Taira, A.; Kiyokawa, S.; Aoike, K.; Saito, S. Accretion tectonics of the Japanese islands and evolution of continental crust. Earth Planet. Sci. 1997, 325, 467-478, (in English with French title and abstract).

20. Isozaki, Y.; Aoki, K.; Nakama, T.; Yanai, S. New insight into a subduction-related orogen: A reappraisal of the geotectonic framework and evolution of the Japanese Islands. Gondwana Res. 2010, 18, 82-105. [CrossRef]

21. Riede, F.; Barnes, G.; Elson, M.D.; Oetelaar, G.A.; Holmberg, K.G.; Sheets, P. Prospects and pitfalls in integrating volcanology and archaeology: A review. J. Volcanol. Geotherm. Res. 2020, 401, 106977. [CrossRef]

22. Soda, T. Tephroarchaeology and its history in Japan. In TephroArchaeology in the North Pacific; Barnes, G.L., Soda, T., Eds.; Archaeopress: Oxford, UK, 2019; pp. 24-40.

23. Barnes, G.L.; Soda, T. (Eds.) TephroArchaeology in the North Pacific; Archaeopress: Oxford, UK, 2019.

24. Barnes, G.L. Earthquake archaeology in Japan: An overview. In Ancient Earthquakes; Sintubin, M., Stewart, I.S., Niemi, T.M., Altunel, E., Eds.; GSA Special Paper 471; Geological Society of America: Boulder, CO, USA, 2010; pp. 81-96.

25. Barnes, G.L. The search for tsunami evidence in the geological and archaeological records, with a focus on Japan. Asian Perspect. 2017, 56, 132-165. [CrossRef]

26. Merriam-Webster Editorial Staff (Ed.) (n.d.). Geo-Combining Form. The Merriam-Webster.com Dictionary. Available online: https: / / www.merriam-webster.com/dictionary / geo- (accessed on 19 March 2021).

27. Smith, P. (Estate); Compound Words in Greek; Pressbooks: Vancouver, CA, USA, 2016. Available online: https://pressbooks. bccampus.ca/greeklatinroots2/chapter/\%C2\%A7110-some-common-greek-combining-forms/ (accessed on 19 March 2021).

28. Renfrew, C. Archaeology and the earth sciences. In Geoarchaeology: Earth Science and the Past; Davidson, D.A., Shackley, M.L., Eds.; Duckworth: London, UK, 1976; pp. 1-5.

29. Davidson, D.A.; Shackley, M.L. (Eds.) Geoarchaeology: Earth Science and the Past; Duckworth: London, UK, 1976.

30. Schiffer, M. Formation Process of the Archaeological Record; University of New Mexico Press: Albuquerque, NM, USA, 1987.

31. Karkanas, P.T.; Goldberg, P. Reconstructing Archaeological Sites: Understanding the Geoarchaeological Materix; John Wiley \& Sons: Oxford, UK, 2019.

32. Stein, J.K.; Farrand, W.R. (Eds.) Archaeological Sediments in Context; Study of Early Man, Institute for Quaternary Studies, University of Maine at Orono: Orono, ME, USA, 1985.

33. Stein, J.K.; Farrand, W.R. (Eds.) Sediments in Archaeological Context; University of Utah Press: Salt Lake City, UT, USA, 2001.

34. Pollard, A.M. (Ed.) Geoarchaeology: Exploration, Environments, Resources; Special Publication No. 165; The Geological Society: London, UK, 1999.

35. Pollard, A.M. (n.d.) Staff Page at Oxford. Available online: https://www.arch.ox.ac.uk/people/pollard-mark (accessed on 19 March 2021).

36. ITA (Information Technology Associates). Dictionary of Geology. 2019. Available online: https://theodora.com/geology/index. html (accessed on 19 March 2021).

37. Colpron, M.; Nelson, J.L.; Murphy, D.C. Northern Cordilleran terranes and their interactions through time. GSA Today 2007, 17, 4. [CrossRef]

38. Stein, J.K. Effects of scale on archaeological and geological perspectives. In Effects of Scale on Archaeological and Geoscientific Perspectives; Stein, J.K., Linse, A.R., Eds.; GSA Special Paper 283; The Geological Society of America: Boulder, CO, USA, 1993; pp. 1-10. 
39. Waters, M.R. Principles of Geoarchaeology: A North America Perspective; Paperback Edition in 1997; University of Arizona Press: Tuscon, AZ, USA, 1992.

40. Pollard, A.M. Geoarchaeology: An introduction. In Geoarchaeology: Exploration, Environments, Resources; Special Publication No. 165; The Geological Society: London, UK, 1999; pp. 7-14.

41. Hassan, F.A. Geoarchaeology: The geologist and archaeology. Am. Antiq. 1979, 44, 267-270. [CrossRef]

42. Rapp, G., Jr. Archaeological geology. In Encyclopedia of Physical Science and Technology; Meyers, R.A., Ed.; Academic Press: New York, NY, USA, 1987; Volume 1, pp. 688-698.

43. Rapp, G., Jr. Geoarchaeology. Annu. Rev. Earth Planet. Sci. 1987, 15, 97-113. [CrossRef]

44. Thorson, R.M.; Holliday, V.T. Just what is geoarchaeology? Geotimes 1990, 1990, 19-20.

45. Rapp, G., Jr.; Hill, C.L. Geoarchaeology: The Earth-Science Approach to Archaeological Interpretation, 1st ed.; Yale University Press: New Haven, CT, USA, 2009.

46. Hill, C.L. Geoarchaeology, history. In Encyclopedia of Geoarchaeology; Gilbert, A.S., Ed.; Springer: Berlin, Germany, 2017; pp. 292-303. [CrossRef]

47. Keller, E.A.; Pinter, N. Active Tectonics: Earthquakes, Uplift, and Landscape; Prentice Hall: Hoboken, NJ, USA, 2002.

48. Inaga, S. Addressing trade from the historical perspective of pirates. In Aporia in Pre-Modern East Asia; Xu, X., Ed.; Japanese Studies Series 8; National Taiwan University Publishing Center: Taipei, Taiwan, 2014; pp. 123-152. (In Japanese)

49. Morgan, W.J. Rises, trenches, great faults, and crustal blocks. J. Geophys. Res. 1968, 73, 1959-1982. [CrossRef]

50. McKenzie, D.P.; Parker, R.L. The North Pacific: An example of tectonics on a sphere. Nature 1967, 216, 1276-1289. [CrossRef]

51. Dickinson, W.R.; Burley, D.V. Geoarchaeology of Tonga: Geotectonic and geomorphic controls. Geoarchaeology 2007, 22, 231-261. [CrossRef]

52. Jing, Z. Integration comes of age: A conversation with Rip Rapp. Geoarchaeology 2007, 22, 1-14. [CrossRef]

53. National Science Foundation (n.d.) Geosciences (GEO): About Earth Sciences. National Science Foundation Where Discoveries Begin. Available online: https:/ / www.nsf.gov/geo/ear/about.jsp (accessed on 19 March 2021).

54. Kearey, P.; Klepeis, K.A.; Vine, F.J. Global Tectonics; Wiley-Blackwell: Oxford, UK, 2009.

55. Blackett, P.M.S.; Bullard, E.; Runcorn, S.K. (Eds.) A Symposium on Continental Drift, Held in 28 October 1965; Philosophical Transactions of the Royal Society A. No. 258; The Royal Society of London: London, UK, 1965.

56. Wiley Online Library. Available online: https:/ / onlinelibrary.wiley.com/ (accessed on 19 March 2021).

57. Elsiever ScienceDirect. Available online: https:/ /www.sciencedirect.com/ (accessed on 19 March 2021).

58. RESET. Available online: http:/ / 14.arch.ox.ac.uk/reset/index.html (accessed on 19 March 2021).

59. Butzer, K.W. Geo-archaeological interpretation of Acheulian calc-pan sites at Doornlaagte and Rooidam. J. Archaeol. Sci. 1974, 1, 1-25. [CrossRef]

60. Edwards, K.J. Editorial: Anatomy of a publication. The Journal of Archaeological Science, the first nine years. J. Archaeol. Sci. 1983, 10, 413-421.

61. Finkl, C. In Memoriam: Rhodes W. Fairbridge. J. Coast. Res. 2007, 23, iii.

62. Gould, R. Disaster Archaeology; Unversity of Utah Press: Salt Lake, UT, USA, 2007.

63. Grattan, J.; Torrence, R. (Eds.) Living under the Shadow: Cultural Impacts of Volcanic Eruptions; Left Coast: Walnut Creek, CA, USA, 2007.

64. Sheets, P.D. Archeological Studies of Disaster: Their Range and Value; Natural Hazard Research Working Paper \#38; Institute of Behavioral Science, University of Colorado: Boulder, CO, USA, 1980.

65. Kuwahata, M. Volcanic disaster archaeology: Comments on methodological prospects and issues. In TephroArchaeology in the North Pacific; Barnes, G.L., Soda, T., Eds.; Archaeopress: Oxford, UK, 2019; pp. 41-46.

66. Kuwahata, M. Restoration of agricultural assets after volcanic disasters in southwest Japan. In TephroArchaeology in the North Pacific; Barnes, G.L., Soda, T., Eds.; Archaeopress: Oxford, UK, 2019; pp. 92-201.

67. Maruyama, K. Volcanic disaster research using archaeological methods: 10th-century eruption and population movements in northern Tohoku, Japan. In TephroArchaeology in the North Pacific; Barnes, G.L., Soda, T., Eds.; Archaeopress: Oxford, UK, 2019; pp. 140-157.

68. Okamura, K.; Fujisawa, A.; Kondo, Y.; Fujimoto, Y.; Uozu, T.; Ogawa, Y.; Kaner, S.; Mizoguchi, K. The Great East Japan Earthquake and cultural heritage: Towards an archaeology of disaster. Antiquity 2013, 87, 258-269. [CrossRef]

69. Shimoyama, S. On the range of the Disaster Archaeology-For taking measure of effects from disasters. Hominids 1997, 1, 83-103. (In Japanese with English title and summary)

70. Sugiyama, H. Investigations into the Kofun period disasters caused by Mt Haruna eruptions. In TephroArchaeology in the North Pacific; Barnes, G.L., Soda, T., Eds.; Archaeopress: Oxford, UK, 2019; pp. 168-182.

71. Torrence, R. Social resilience and long-term adaptation to volcanic disasters: The archaeology of continuity and innovation in the Willaumez Peninsula, Papua New Guinea. Quat. Int. 2016, 394, 6-16. [CrossRef]

72. Torrence, R.; Grattan, J. (Eds.) Natural Disasters and Cultural Change; Routledge: London, UK, 2002.

73. Wright, H.T. In Memoriam: William R. Farrand (1931-2011). Paleorient 2011, 37, 5-8.

74. Barnes, G.L. Book review of Rapp \& Gifford, Archaeological Geology. Geol. Mag. 1986, 122, 89-90.

75. Bailey, G.N.; Reynolds, S.C.; King, G.C.P. Landscapes of human evolution: Models and methods of tectonic geomorphology and the reconstruction of hominin landscapes. J. Hum. Evol. 2011, 60, 257-280. [CrossRef] 
76. Goldberg, P.; Holliday, V.T.; Ferring, C.R. (Eds.) Earth Sciences and Archaeology; Kluwer: New York, NY, USA, 2001.

77. Barnes, G.L. Tephrogenic soils of Japan in comparative context. In TephroArchaeology in the North Pacific; Barnes, G.L., Soda, T., Eds.; Archaeopress: Oxford, UK, 2019; pp. 202-233.

78. Tan, K.H. (Ed.) Andosols; Van Nostrand Reinhold: New York, NY, USA, 1984.

79. Sensoft [sic]. How Deep Can GPR See? Gpr Depth. 2016. Available online: Sensoft.ca/gpr/depth-deep (accessed on 19 March 2021).

80. Ross, C.S.; Shannon, E.V. The minerals of bentonite and related clays and their physical properties. J. Am. Ceram. Soc. 1926, 9 , 77-96. [CrossRef]

81. Anonymous. 1755 the Great Lisbon Earthquake and Tsunami, Portugal. SMS Tsunami Warning. 2018. Available online: www.sms-tsunami-warning.com/pages/tsunami-portugal-1755\#.XgXy8Bew1Sw (accessed on 19 March 2021).

82. Gilbert, A.S. Encyclopedia of Geoarchaeology; Springer: Dordrecht, The Nederland, 2017.

83. DCAN (Disaster Concerned Archaeologists' Network) \& Maizo Bunkazai Kenkyukai. Hakkutsu sareta Jishin Konseki [Excavated Evidence of Earthquakes]; Maibun Kankei Kyuen Renraku Kaigi: Osaka, Japan, 1996. (In Japanese)

84. Bullough, F. Geoscience and the future-A timer for a reboot? Geoscientist 2020, 26-27.

85. Tazaki, K. Green-tuff landslide areas are beneficial for rice nutrition in Japan. Anais da Acad. Bras. de Ciências 2006, 78, 749-763. [CrossRef] [PubMed]

86. Barnes, G.L. Tectonic Archaeology; (in preparation)

87. Sakaguchi, H. Archaeological investigation of the seasonality and duration of the 6th-century eruptions from Mt Haruna. In TephroArchaeology in the North Pacific; Barnes, G.L., Soda, T., Eds.; Archaeopress: Oxford, UK, 2019; pp. $184-191$.

88. Saino, H. Investigate Method of Tsunami Disaster Traces: Cooperation with Concerned Many Fields; Doseisha: Tokyo, Japan, 2017. (In Japanese)

89. Matsuda, J.-I. Seismic deformation structures of the post-2300 a BP muddy sediments in Kawachi lowland plain, Osaka, Japan. Sediment. Geol. 2000, 135, 99-116. [CrossRef]

90. Harlow, G.E.; Sorensen, S.S.; Sisson, V.B.; Shi, G. Chapter 10: The geology of jade deposits. In The Geology of Gem Deposits; Groat, L.A., Ed.; Mineralogical Association of Canada: Québec, QC, Canada, 2014; pp. 305-374.

91. Harlow, G.E.; Tsujimori, T.; Sorensen, S.S. Jadeitites and plate tectonics. Annu. Rev. Earth Planet. Sci. 2015, 43, 105-138. [CrossRef]

92. Lake, D.J. Geology: Earth Science for Everyone. 2020. Available online: https://www.udemy.com/course/geology-earth-sciencefor-everyone (accessed on 19 March 2021).

93. Kearey, P.; Vine, F.J. Global Tectonics; Blackwell Science: Oxford, UK, 1996.

94. Frisch, W.; Meschede, M.; Blakey, R.C. Plate Tectonics: Continental Drift and Mountain Building; Springer: Heidelberg, Germany, 2011.

95. Moores, E.M.; Twiss, R.J. Tectonics; Waveland Press, Inc.: Long Grove, IL, USA, 1995; (reprinted in 2014).

96. Kaizuka, S. Tectonic landforms. In Landforms of Japan; Yoshikawa, T., Kaizuka, S., Ota, Y., Eds.; University of Tokyo Press: Tokyo, Japan, 1981; pp. 39-72.

97. Bull, W.B. Tectonic geomorphology. J. Geol. Educ. 1984, 32, 310-324. [CrossRef]

98. Yonekura, N.; Okada, A.; Moriyama, A. (Eds.) Tectonic Geomorphology and Tectonics; Kokon Shoin: Tokyo, Japan, 1990. (In Japanese)

99. Suzuki, Y. Tectonic geomorphological Active Fault studies in Japan after 1980. Geogr. Rev. Jpn. Ser. B 2013, 86, 6-13.

100. Bull, W.B. Tectonic Geomorphology of Mountains: A New Approach to Paleioseismology; John Wiley \& Sons: Chichester, UK, 2008.

101. Bull, W.B. Tectonically Active Landscapes; John Wiley \& Sons: Chichester, UK, 2009.

102. Burbank, D.W.; Anderson, R.S. Tectonic Geomorphology; John Wiley \& Sons: Chichester, UK, 2011.

103. Wobus, C.; Whipple, K.X.; Kirby, E.; Snyder, N.; Johnson, J.; Spyropolou, K.; Crosby, B.; Willett, S.D. Tectonics from topography: Procedures, promise, and pitfalls. In Tectonics, Climate, and Landscape Evolution; Willet, S.D., Hovius, N., Brandon, M.T., Fisher, D.M., Eds.; GSA Special Paper 398; Geological Society of America: Boulder, CO, USA, 2006; pp. 55-74.

104. Kübler, S.; King, G.C.P.; Devès, M.; Inglis, R.H.; Bailey, G.N. Tectonic geomorphology and soil edaphics as controls on animal migrations and human dispersal patterns. In Geological Setting, Palaeoenvironment and Archaeology of the Red Sea; Rasul, N.M.A., Stewart, I.C.F., Eds.; Springer Nature: Cham, Switzerland, 2019; pp. 653-673.

105. Herz, N.; Garrison, E.G. Geological Methods for Archaeology; Oxford University Press: New York, NY, USA, 1998. 